\title{
PENGARUH STATUS KEPEGAWAIAN TERHADAP KEPUASAN KERJA DAN KOMITMEN ORGANISASIONAL
}

\author{
Dijah Julindrastuti, Iman Karyadi \\ Fakultas Ekonomi dan Bisnis Universitas Wijaya Kusuma Surabaya \\ e-mail: dijah.julind@gmail.com
}

\begin{abstract}
Research with the title The Effect of Employment Status on Job Satisfaction and Organizational Commitment takes the object of non-educational employees at UWKS Surabaya where this research was conducted to see whether employees with contract employee status and employees with permanent employee status have differences in job satisfaction and organizational commitment and to see whether job satisfaction influences organizational commitment. The population in this study were all non-educational employees at Universitas Wijaya Kusuma Surabaya. Sampling in this study was carried out using the convenience sampling method. In this study, the researcher distributed questionnaires to 70 respondents, and 60 have returned. To test hypotheses 1 and 2 using the independent sample t-test and hypothesis 3 using multiple linear regression analysis. After testing, the results showed that the work decision between Contract employees with employees were still no different, likewise, for organizational commitment, there was also no difference, whereas, for the effect of job satisfaction on organizational commitment, the results showed that job satisfaction affected organizational commitment, where if job satisfaction increases, organizational commitment will also increase or it was said that between job satisfaction and organizational commitment had a positive effect.
\end{abstract}

Key Words: employment status, job satisfaction, organizational commitment

\begin{abstract}
ABSTRAK
Penelitian dilakukan untuk mengetahui dan membuktikan apakah karyawan dengan status karyawan kontrak dan karyawan dengan status karyawan tetap memiliki perbedaan dalam kepuasan kerja dan komitmen organisasinya serta untuk melihat apakah kepuasan kerja memiliki pengaruh terhadap komitmen organisasional.Populasi dalam penelitian ini adalah seluruh karyawan Non Edukatif pada Universitas Wijaya Kusuma Surabaya. Pengambilan sampel dalam penelitian ini dilakukan dengan menggunakan metode convinience sampling. Dari kuesioner yang disebarkan kepada responden diperoleh hasil sebanyak 70 yang bisa diolah. Untuk menguji hipotesis 1 dan 2 menggunakan independent sample $\mathrm{t}$ test dan hipotesis 3 menggunakan analisa regresi linier berganda.Setelah dilakukan pengujian didapatkan hasil bahwa kepusan kerja antara karyawan kontrak dengan karyawam tetap tidak berbeda demikian juga untuk komitmen organisasionalnya juga tidak terdapat perbedaan sedangkan untuk pengaruh kepuasan kerja terhadap komitmen organisasional didapatkan hasil bahwa kepuasan kerja mempengaruhi komitmen organisasional
\end{abstract}

Kata Kunci: status kepegawaian, kepuasan kerja, komitmen organisasional

\section{PENDAHULUAN}

Tahun 1997 memaksa pemerintah mengambil Kebijakan Pasar Kerja Fleksibel dimana kebijakan ini diminta oleh International Monetary Fund (IMF), World Bank dan Interntional Labour Organization (ILO) sebagai syarat pemberian bantuan untuk menangani krisis ekonomi yang terjadi di Indonesia. Dari kebijakan IMF dan ILO tersebut muncul kebijakan yang berkaitan dengan status kepegawaian kontrak yang dari sisi karyawan hal ini akan sangat merugikan. Status kepegawaian bagi karyawan akan berpengaruh terhadap kepuasan dan komitmen pada diri masing-masing karyawan dan organisasi. Handoko (2001) mengemukakan "kepuasan kerja itu dapat terjadi, dapat dilihat dari keadaan emosional yang menyenangkan atau tidak menyenangkan dengan mana karyawan memandang pekerjaan mereka“. Kepuasan kerja terdiri dari faktor-faktor kemampuan pekerjaan itu sendiri, gaji, peningkatan karir, rekan kerja dan pengawasan atasan (Gunduz et al., 2012). Perlakuan-perlakuan tersebut tersebut oleh 
p-ISSN 1693-1378

e-ISSN 2598-9952

karyawan akan dapat menimbulkan sikap komitmen pada diri karyawan terhadap organisasinya. Status yang tidak memberikan kejelasan pada masa depan karyawan untuk jangka panjang tidak menutup kemungkinan akan terjadi ketidakpuasan kerja sehingga akan memepengaruhi komitmen karyawan pada organisasi di mana dia bekerja. Sikap komitmen pada diri karyawan dan organisasi akan muncul dengan diterimanya perlakukan-perlakuan tersebut. Dari penelitian yang dilakukan oleh Aydogdu dan Aikgil (2011) berkaitan dengan kepuasan dan Seong (2011) untuk komitmen organisasi menunjukkan bahwa status karyawan kontrak yang tidak bisa memberikan kejelasan dan perasaan aman untuk jangka panjang akan bisa menyebabkan terjadinya ketidakpuasan yang mana hal ini akan berdampak terhadap komitmen mereka terhadap organisasi dimana mereka berada. Safitri (2014) menyatakan suatu organisasi, apapun bentuknya sangat memerlukan adanya komitmen yang tinggi dari seluruh anggotanya sehingga tujuantujuan organisasi dan individu dapat tercapai.Burgess (2006) menunjukkan bahwa terdapat perbedaan kepuasan kerja antara pegawai kontrak dengan pegawai tetap. Secara umum penggunaan pekerja kontrak tidak sesuai dengan strategi SDM yang mempromosikan komitmen organisasioanl yang tinggi dan kinerja yang tinggi. Adanya status kepegawaian kontrak dan tetap secara psikologis akan memunculkan perilaku yang berbeda. Karyawan dengan status pegawai tetap memiliki perasaan yang lebih aman dan nyaman dalam bekerja dibandingkan dengan karyawan yang berstatus kontrak. Karyawan dengan status pegawai tetap memiliki beberapa keunggulan dibandingkan dengan pegawai kontrak yang memiliki gaji tetap, asuransi kesehatan,asuransi kecelakaan kerja serta kesempatan untuk promosi jabatan. Karyawan dengan status pegawai tetap, akan berusaha mempertahankan statusnya tersebut dengan bekerja giat untuk memajukan perusahaan dan tidak ingin keluar dari perusahaan.Keadaan diatas akan berbeda dengan karyawan dengan status pegawai kontrak di mana kondisi tersebut bagi karyawan dengan status kontrak tidak akan mereka dapatkan. Perbedaan itulah yang pada akhirnya akan mempengaruhi komitmen mereka terhadap organisasi atau perusahaan di mana mereka bekerja. Selain itu para pekerja kontrak merasa dirinya tidak dilibatkan dan tidak memiliki
Pengaruh Status Kepegawaian Terhadap... (Dijah Julindrastuti, Iman Karyadi)

kesempatan untuk dipromosikan dibandingkan dengan pegawai tetap (Burgess, 2006) Perbedaan tingkat kepuasan kerja berdasarkan status kepegawaiannya juga dibuktikan berdasarkan hasil penelitian yang dilakukan oleh Wickramasinghe (2011) dan Graaf (2012). Karyawan dengan status karyawan tetap akan merasa lebih nyaman dibandingkan dengan karyawan yang berstatus kontrak sehingga komitmen mereka terhadap organisasi juga kan lebih baik. Dari uraian tersebut dikaitkan dengan teori yang ada menyatakan bahwa kepuasan kerja secara umum dapat ditentukan dengan perbedaan yang terjadi antara perasaan yang seharusnya dirasakan oleh karyawan dari pekerjaan yang dilakukan dengan kondisi nyata yang saat ini dirasakan oleh karyawan (Han et al., 2012). Berdasarkan latar belakan tersebut maka rumusan masalah adalah sebagai berikut:

- Apakah ada perbedaan kepuasan kerja berdasarkan status kepegawaian karyawan Non Edukatif Universitas Wijaya Kusuma Surabaya?

- Apakah ada perbedaan komitmen organisasional berdasarkan status kepegawaian karyawan Non Edukatif Universitas Wijaya Kusuma Surabaya?

- Apakah ada pengaruh yang signifikan kepuasan kerja terhadap komitmen organisasional karyawan Non Edukatif Universitas Wijaya Kusuma Surabaya?

\section{METODE PENELITIAN}

Populasi adalah keseluruhan kelompok orang, kejadian atau hal minat yang ingin penelti investigasi (Sekaran, 2006). Populasi penelitian adalah seluruh karyawan Non Edukatif Universitas Wijaya Kusuma Surabaya. Digunakannya karyawan non edukatif dalam penelitian ini karena terkait dengan tujuan penelitian yang disampaikan diatas diperlukan adanya karyawan yang memiliki status kontrak yang mana ini terdapat pada karyawan non edukatif. Karyawan dengan status kontrak tidak dijumpai pada karyawan edukatif. Hal ini yang menjadi dasar bagi peneliti untuk memakai karyawan non edukatif sebagai populasinya.

Teknik sampling dalam penelitian ini menggunakan teknik non-probability sampling yang di dalamnya dilakukan dengan teknik convenience sampling yaitu sampel yang mudah tersedia. Penentuan sampel memakai teori dari sekaran (1992) yang memberikan pedoman 
tentang ukuran sampel, yaitu ukuran sampel lebih dari 30 dan kurang dari 500 adalah tepat untuk semua riset. Selain itu menurut Roscoe dalam buku Sugiyono (2011 : 90) memberikan saran tentang ukuran sampel dalam penelitian bilamana sampel dibagi dalam kategori (misal pria-wanita, PNS-swasta dan lain-lain) maka anggota sampel setiap kategori minimal 30. Oleh karena itu, peneliti akan menyebarkan kuisioner kepada 70 responden dengan rincian ada 35 karyawan tetap dan 35 karyawan kontrak dengan harapan diperoleh kuisioner yang kembali minimal sebanyak 60 baik untuk karyawan tetap maupun untuk karyawan kontrak.

Status Kepegawaian $\left(\mathrm{X}_{1}\right)$, status kepegawaian dalam penelitian ini dibedakan menjadi karyawan dengan status tetap dan karyawan dengan status kontrak. Karyawan dengan status tetap dikode 1 dan karyawan dengan status kontrak dikode 2 .

Menurut Robbins (2002, p. 45) Kepuasan Kerja $\left(\mathrm{X}_{2}\right)$, adalah keadaan emosional yang menyenangkan atau tidak menyenangkan dengan mana para karyawan memandang pekerjaan mereka. Indikator-indikator dari kepuasan kerja adalah kepuasan terhadap pekerjaan, pekerjaan dapat mengembangkan diri pegawai, pendapatan yang sesuai dengan kontribusi, gaji yang sesuai dengan standart upah minimum, kesempatan karier yang berkembang, memberikan kesempatan pegawai untuk maju, rekan kerja yang saling membantu dalam penyelesaian pekerjaan, rekan kerja yang bisa bekerjasama dalam pekerjaan, atasan yang mau berdiskusi untuk meminta pendapat tentang pekerjaan, atasan yang bersedia memberikan pengarahan dalam pekerjaaan.

Komitmen Organisasioanal (Y), merupakan suatu keinginan yang dimiliki oleh anggota untuk tetap bertahan dalam organisasi dan berusaha dengan keras untuk mewujudkan keinginan tersebut. Meyer dan Allen (1991) mendefinisikan komitmen organisasional menjadi 3 yang terdiri dari komitmen afektif, komitmen berkesinambungan dan komitmen normatif.

Komitmen afektif adalah komitmen yang menunjukkan adanya keterikatan emosional pekerja, identifikasi dan keterlibatan pekerja pada organisasi. Indikator komitmen organisasional afektif adalah terdiri dari kesenangan menghabiskan sisa karir dengan perusahaan, senang membahas perusahaan dengan orang-orang di luar perusahaan, merasa bahwa masalah perusahaan ini juga menjadi masalah pribadi, dengan mudah menjadi bagian dari perusahaan lain seperti berada di perusahaan ini (R), merasa menjadi 'bagian keluarga' pada perusahaan tempat bekerja, memiliki ikatan 'emosional' dengan perusahaan tempat bekerja, perusahaan ini memiliki makna yang berharga, punya rasa memiliki yang kuat terhadap tempat bekerja

Komitmen berkesinambungan (continuance) terjadi bilaman dalam diri karyawan tetap bertahan pada organisasi karena kebutuhan akan gaji serta kebutuhan lainnya yang bisa memberikan keuntungan, atau karena tidak ada pekerjaan lain yang bisa dilakukan.. Indikator komitmen organisasional continuance adalah tidak takut jika berhenti dari pekerjaan, sulit meninggalkan organisasi, banyak kehidupan yang terganggu jika meninggalkan organisasi, besar kerugian jika meninggalkan organisasi, tetap tinggal di organisasi adalah kebutuhan, sedikit pilihan untuk keluar dari organisasi,sedikit alternatif tempat bekerja lainnya,keluar dari organisasi membutuhkan pengorbanan besar

Komitmen normatif adalah perasaan untuk bertahan pada organisasi dikarenakan adanya kewajiban dan tanggungjawab yang dimiliki dimana norma, nilai dan keyakinan yang menjadi pertimbangan.. Indikator komitmen organisasional continuance adalah seharusnya orang tidak gampang berpindah ke perusahaan lain, orang seharusnya loyal pada organisasinya, berpindah ke organisasi lain adalah hal yang tidak etis, punya kewajiban moral untuk tinggal, tidak tepat untuk meninggalkan organisasi, meyakini nilai tetap loyal pada organisasi, Lebih baik jika tetap tinggal di organisasi, keinginan untuk menjadi orang di perusahaan adalah bijaksana.Dalam membuat kuesioner untuk keperluan penelitian dilakukan dengan mengadopsi dari peneliti lain dengan menggunakan dasar teori dari Meyer dan Allen (1991).

Teknik analisa yang digunakan adalah independent sample $t$ test untuk melihat perbedaan komitmen organisasi dan kepuasan kerja berdasar status kepegawaian $\left(\mathrm{H}_{1}\right.$ dan $\left.\mathrm{H}_{2}\right)$ dam analisa regresi berganda untuk melihat pengaruh kepuasan kerja terhadap komitmen organisasi $\left(\mathrm{H}_{3}\right)$. 

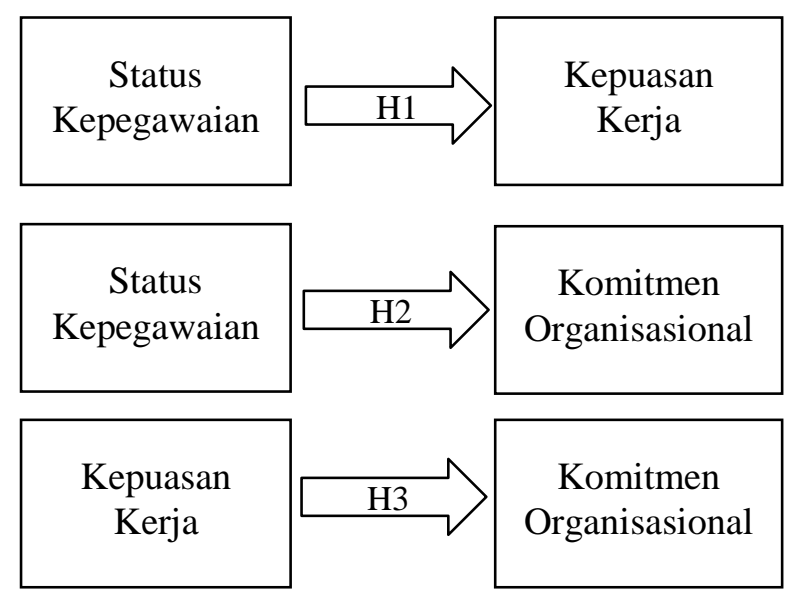

\section{Gambar 1 Model Penelitian}

\section{PEMBAHASAN}

Penelitian ini menggunakan data primer yang diperoleh peneliti dengan menggunakan metode survey. Peneliti bermaksud menyebarkan kuisioner berisi pertanyaan tentang kepuasan kerja, status kepegawaian dan komitmen organisasional pada karyawan Non Edukatif Universitas Wijaya Kusuma Surabaya. Berdasarkan hipotesis yang diajukan yaitu utk $\mathrm{H}_{1}$ : Terdapat perbedaan kepuasan kerja antara karyawan tetap dan karyawan kontrak, $\mathrm{H}_{2}$ : Terdapat perbedaan komitmen organisasional antara karyawan tetap dan karyawan kontrak dan $\mathrm{H}_{3}$ : Kepuasan kerja berpengaruh positif signifikan terhadap komitmen organisasional maka dilakukan pengujian untuk bisa membuktikan hipotesis tersebut.

Tabel 1

Hasil Uji Hipotesis 1

\begin{tabular}{|c|c|c|}
\hline Status Karyawan & Mean & Sig \\
\hline Karyawan tetap & 3.4600 & \\
Karyawan kontrak & 3.6343 & 0.233 \\
\hline
\end{tabular}

Hasil pengujian SPSS untuk hipotesi 1 menunjukkan hasil untuk kepuasan kerja karyawan tetap sebesar 3.4600 adalah lebih kecil dari kepuasan kerja karyawan kontrak sebesar 3.6343 namun Dengan demikian Kepuasan kerja pegawai tetap sama dengan Kepuasan kerja pegawai kontrak. Hasil penelitian ini tidak
Pengaruh Status Kepegawaian Terhadap... (Dijah Julindrastuti, Iman Karyadi)

mendukung penelitian yang dilakukan oleh Burgess (2006), Wickramasinghe (2011) serta Graaf (2012).

Berdasarkan analisa dari penelitian ini dimana tidak terdapat perbedaan kepuasan kerja pegawai tetap dan pegawai kontrak diantaranya disebabkan karena faktor gaji yang diterima pegawai tetap dan pegawai kontrak yang tidak terlalu berbeda, kesempatan untuk mendapatkan pengembangan karir yang sama serta peran dari rekan kerja dalam menjalankan pekerjaan yang saling mendukung. Faktor gaji yang seringkali dipakai sebagai standar untuk pemenuhan kebutuhan hidup sehari-hari terutama yang menjadikan alasan dalam penelitian ini yang menunjukkan hasil tidak ada perbedaan kepuasan kerja pegawai tetap dan pegawai kontrak. Untuk pegawai yang berada pada level menengah ke bawah orientasi mereka adalah pada besarnya pendapatan yang mereka terima disamping juga penerimaan gaji yang tepat waktu.

Tabel 2

Hasil Uji Hipotesis 2

\begin{tabular}{|c|c|c|}
\hline Status Karyawan & Mean & Sig \\
\hline Karyawan tetap & 3.6103 & \multirow{2}{*}{0.292} \\
\hline Karyawan kontrak & 3.7494 & \\
\hline
\end{tabular}

Hasil uji untuk hipotesis 2 menunjukkan hasil untuk komitmen organisasi karyawan tetap sebesar 3.6103 adalah lebih kecil dari komitmen organisasi karyawan kontrak sebesar 3.7494 namun perbedaan tidak signifikan $(0,292>0,05)$. Dengan demikian Komitmen Organisasi pegawai tetap sama dengan Komitmen Organisasi pegawai kontrak. Hasil ini berbeda dengan penelitian yang dilakukan oleh Seong (2011), Purwanto (2010) serta Safitri (2014).

Berdasarkan analisa dalam penelitian ini dimana tidak terdapat perbedaan komitmen organisasional pegawai tetap dan pegawai kontrak diantaranya disebabkan dari latar belakang mereka bekerja. Memiliki pekerjaan juga mempengaruhi status sosial mereka dalam masyarakat. Dari uraian tersebut bisa dikatakan bahwa komitmen organisasional antara pegawai tetap dan pegawai kontrak adalah sama. Alasan ini sebetulnya juga hampir dimiliki oleh sebagian besar pegawai terutama yang berada pada level menengah ke bawah, dimana dalam komitmen 
berkesinambungan yang disampaikan oleh Mayer dan Allen bahwa memiliki pekerjaan adalah suatu kebutuhan untuk setiap karyawan. Kondisi lapangan kerja yang semakin sempit membuat orang akan berpikir lebih dalam untuk meninggalkan pekerjaannya.Faktor lain yang juga bisa menjadi alasan mengapa komitmen organisasional antara pegawai tetap dan pegawai kontrak tidak terdapat perbedaan adalah karena adanya keinginan dari mereka untuk menghabiskan karir di organisasi ini karena faktor usia, jenjang pendidikan serta pengalaman kerja yang mereka miliki.Dari survey yang dilakukan untuk karyawan tetap dan kontrak rata-rata usia adalah 40 - 50 tahun dimana untuk usia ini sangat sulit kalau harus berpindah kerja. Jenjang pendidikan untuk karyawan tetap dan kontrak adalah S1 sebanyak 31\% dan SLTA sebanyak $30 \%$ Yang memang sudah sesuai dengan pekerjaan yang mereka jalani.

Hasil uji hipotesis mendukung pengaruh Kepuasan kerja terhadap Komitmen Organisasional Hal ini dapat dilihat dari signifikansi $\mathrm{F}$ dan $\mathrm{t}$ sebesar 0,000. Adapun persamaan regresi sederhana adalah $\mathrm{KO}=1447+$ 0,629 KK. Dari persamaan regresi sederhana tersebut, dapat dilihat bahwa koefisien regresi (b) Komitmen organisasi sebesar 0,629.

Tabel 3

Hasil Uji Hipotesis 3

\begin{tabular}{|c|c|c|}
\hline Model & T & Sig. \\
\hline (Constant) & 5,135 & 0,0005 \\
KK & 8,033 & 0,0005 \\
\hline
\end{tabular}

Hasil pengujian hipotesis 3 menunjukkan bahwa terdapat hubungan positif (searah) antara Komitmen organisasi dengan Kepuasan kerja. Hal ini berarti menunjukkan jika Kepuasan kerja meningkat maka Komitmen Organisasi juga meningkat dan jika Kepuasan kerja menurun maka Komitmen organisasi juga menurun.

Hasil pengujian ini mendukung penelitian Aydogdu dan Asikgil (2011), Susanj and Jakopec (2012) serta Boles et al (2007) dimana terdapat hubungan positif antara kepuasan kerja terhadap komitmen organisasional.

\section{PENUTUP}

\section{Kesimpulan}

Hasil analisis untuk H1 menunjukkan bahwa kepuasan kerja pegawai tetap dan pegawai kontrak adalah sama. Hal ini berarti kepuasan kerja untuk karyawan tetap dan karyawan kontrak adalah sama. Hasil analisis untuk $\mathrm{H} 2$ menunjukkan bahwa komitmen organisasional pegawai tetap dan pegawai kontrak adalah sama. Hal ini berarti komitmen organisasional untuk karyawan tetap dan karyawan kontrak adalah sama. Kesimpulan ini bisa dilihat berdasarkan hasil uji yang menunjukkan perbedaan yang tidak signifikan pada Komitmen organisasional. Hasil Analisis untuk H3 menunjukkan bahwa Kepuasan kerja berpengaruh positif signifikan terhadap komitmen organisasional.

\section{Keterbatasan dan Rekomendasi Untuk Penelitian Selanjutnya}

Organisasi dalam hal ini adalah Universitas Wijaya Kusuma Surabaya sebaiknya kebijakan terkait dengan Sumber Daya Manusia untuk lebih jelas. Kebijakan yang jelas akan memberi kenyamanan baik untuk karyawan tetap maupun kontrak, seperti misal aturan yang berkaitan dengan kebijakan bagaimana status seorang karyawan bisa berubah dari kontrak menjadi tetap. Untuk penelitian selanjutnya bisa dikembangkan untuk tenaga edukatif dan memakai variabelvariabel yang lain dan juga dengan obyek yang lain.

\section{DAFTAR PUSTAKA}

Alexandrov, Aliosha, Babakus, Emin \& Yavas, Ugur. (2007). Perceived Management Concern for Frontline Employees and Customers on Turnover Intentions : Moderating Role of Employment Status. Journal of Service Research. 9(4), p:356371

Aydogdu, Sinem \& Asikgil, Baris. (2011). An Empirical Study of the Relationship Among Job Satisfaction, Organizational Commitment and Turnover Intention. International Review of Management and Marketing.1(3), pp:43-53

Biggs, David \& Swailes, Stephen. (2006). Relations, Commitment and Satisfaction in Agency Workers and Permanent Workers. Employee Relations. 28(2), Pp:130

Boles, James, Madupalli. Ramana, Rutherford, Brian, Wood. J.Andy. (2007). The Relationship Of Facets Of Salesperson Jobsatisfaction With Affective Organizational Commitment. Journal of Business \& Industrial Marketing. 22(5), 
Pp:311-321

Burgess, John. Julia, Conell. (2006). Temporary Work and Human Resources Management: Issues, Challenges and Responses. Personnel Review; 35(2), pp:129

Djati, S, Pantja dan Khasaini, M. (2003). Kajian Terhadap Kepuasan Kompensasi, Komitmen Organisasional, Dan Prestasi Kerja. Jurnal Manajemen \& Kewirausahaan. 5(1), h:25-41

Feather, N.T. \& Rauter, Katrin, A. (2004). Organizational Behaviours in Relation to Job Status, Job Insecurity, Organizational Commitment and Identification, Job Satisfaction and Work Values. Journal of Occupational and Organizational Psychology. 77, pp:81-94

Graaf, de Marloes. (2012). Job Satisfaction and Contingent Employment. Journal De Economist. 160, pp:197-218

Gunduz, Hulya, C, Gunzel, Ayse dan Ulutas Tugce. (2012). Effects Of Emotional Intelligence On Job Satisfaction: An Empirical Study On Call Center Employees. Procedia - Social and Behavioral Sciences. 58, pp:363 - 369

Handoko, (2001). Manajemen Personalia Dan Sumber Daya Manusia (12th Ed). Yogyakarta: BPFE

Luthans, F. (2006). Perilaku Organisasi (10th Ed). Yogyakarta: ANDI.

Luthans, F. (1998). Organizational Behavior. New York: McGraw-Hill.

McCormack, D., Casimir, G. M., Dyjurkovic, N. \& Yang L. (2009). Workplace Bullying And Intention To Leave Amongst Schoolteachers in China: The mediating effect of affective commitment. Journal of Applied Social Psychology, 39: 2106 - 2127

Sugiyono 2011. Metode Penelitian Kuantitatif, kualitatiftif dan R\&D. Alfabeta.

Robbins, P. Stephen. (2002). Prinsip-Prinsip Perilaku Organisasi. Edisi Kelima. Diterjemahkan oleh: Halida, S.E dan Dewi Sartika, S.S. Erlangga, Jakarta. 